\title{
Prevalence of tetracycline resistance genes among multi-drug resistant bacteria from selected water distribution systems in southwestern Nigeria
}

\author{
Ayodele. T. Adesoji ${ }^{*}$, Adeniyi. A. Ogunjobi ${ }^{2}$ Isaac. O. Olatoye ${ }^{3,4}$ and Douglas. R. Douglas ${ }^{4,5}$
}

\begin{abstract}
Background: Antibiotic resistance genes [ARGs] in aquatic systems have drawn increasing attention they could be transferred horizontally to pathogenic bacteria. Water treatment plants (WTPs) are intended to provide quality and widely available water to the local populace they serve. However, WTPs in developing countries may not be dependable for clean water and they could serve as points of dissemination for antibiotic resistant bacteria. Only a few studies have investigated the occurrence of ARGs among these bacteria including tetracycline resistance genes in water distribution systems in Nigeria.
\end{abstract}

Methodology: Multi-drug resistant (MDR) bacteria, including resistance to tetracycline, were isolated from treated and untreated water distribution systems in southwest Nigeria. MDR bacteria were resistant to $>3$ classes of antibiotics based on break-point assays. Isolates were characterized using partial $16 \mathrm{~S}$ rDNA sequencing and PCR assays for six tetracycline-resistance genes. Plasmid conjugation was evaluated using E. coli strain DH5a as the recipient strain.

Results: Out of the 105 bacteria, 85 (81\%) and 20 (19\%) were Gram- negative or Gram- positive, respectively. Twenty-nine isolates carried at least one of the targeted tetracycline resistance genes including strains of Aeromonas, Alcaligenes, Bacillus, Klebsiella, Leucobacter, Morganella, Proteus and a sequence matching a previously uncultured bacteria. Tet(A) was the most prevalent (16/29) followed by tet(E) $(4 / 29)$ and tet30 (2/29). Tet(O) was not detected in any of the isolates. Tet(A) was mostly found with Alcaligenes strains $(9 / 10)$ and a combination of more than one resistance gene was observed only amongst Alcaligenes strains $[\operatorname{tet}(A)+\operatorname{tet} 30(2 / 10)$, tet $(A)+\operatorname{tet}(E)(3 / 10)$, tet $(\mathrm{E})+\operatorname{tet}(\mathrm{M})(1 / 10)$, tet $(\mathrm{E})+$ tet30 (1/10)]. Tet( $\mathrm{A})$ was transferred by conjugation for five Alcaligenes and two E. coli isolates.

Conclusions: This study found a high prevalence of plasmid-encoded tet( $\mathrm{A})$ among Alcaligenes isolates, raising the possibility that this strain could shuttle resistance plasmids to pathogenic bacteria.

Keywords: Tetracycline resistance, Multidrug resistance, Water treatment, 165 rDNA library

\section{Introduction}

Tetracycline antibiotics have been used to treat infectious diseases for more than half a century [1]; they have also been used nearly as long to promote growth in food animal production systems [2-4]. Growth-promoting properties of tetracyclines were first described in 1949 for chickens fed chlortetracycline supplemented feed [5]. Subsequently, they were widely applied in animal husbandry thanks to improving the growth rate to feed intake ratio [6-8].

\footnotetext{
* Correspondence: timmyayus2002@yahoo.com

'Department of Biological Sciences, Federal University Dutsin-Ma, Dutsin-Ma, Katsina State, Nigeria

Full list of author information is available at the end of the article
}

Tetracycline inhibits bacterial growth by interfering with protein synthesis when the antibiotic binds to the 30S ribosomal subunit thereby preventing aminoacyl-t-RNA binding to the ribosomal A site and preventing synthesis of polypeptides [1]. Resistance to tetracycline is usually conferred through acquisition of resistance genes associated with mobile genetic elements [9]. These genes could be disseminated by interspecies transfer mediated by plasmids, transposons, and bacteriophage $[10,11]$. Once resistance genes are introduced into the environment, they are also exposed to selective pressure, such as antibiotics produced by indigenous antibiotic producers in soil. However, selection can occur in the environment without antibiotic 
selective pressure [12]. For example, Gilliver et al. [13] reported that antibiotic-resistant bacteria were found in wild rodents that had never been exposed to antibiotics. Therefore, antibiotic resistance genes might be distributed and preserved in the broader environment with or without antibiotic selective pressure. Four resistance mechanisms have been described, including protection of the ribosome by a large cytoplasmic protein, energy-dependent efflux, enzymatic inactivation and target modification $[14,15]$.

Several investigators have reported findings for antibiotic resistant bacteria found in finished drinking water based on culture-dependent methods [16], indicator organisms [17] and qualitative and quantitative molecular techniques $[18,19,16]$. Studies have demonstrated that the susceptibility of antibiotic resistant bacteria to a disinfectant and the susceptibility of antibiotic-susceptible bacteria to a disinfectant can be genetically linked $[20,21]$ and thus coselection can occur with disinfectant exposure. Armstrong et al. [22, 23] suggested that stress-tolerant bacteria selected by chlorination might be more antibiotic resistant, and one study found that suboptimal chlorine treatment of drinking water selected for multidrug-resistant Pseudomonas aeruginosa [24]. Xi et al. [16] reported an increased prevalence of antibiotic resistance genes and specialized groups of antibiotic resistant bacteria in tap water compared to source water and they, suggested that water treatment could differentially favor the antibiotic resistant bacteria and/or induce transfer of antibiotic resistance genes among subsets of the bacterial population. Figueira et al. [25] studied different populations of waste water $E$. coli and concluded that variations on the prevalence of quinolone resistance were correlated with the dynamics of some population sub-sets. Vaz-Moreira et al. [26] characterized patterns of antimicrobial resistance for sphingomonads isolated from tap water and cup fillers of dental chairs. They also concluded that antibiotic resistance patterns are often species- rather than site-related. There is a paucity of information on the prevalence of tetracycline resistance genes among bacteria isolates from treated and untreated water in Nigeria. The goal of this study was to estimate the prevalence of select tetracycline resistance genes among bacteria from isolated water distribution systems in south-west Nigeria.

\section{Materials and methods}

\section{Site description}

Samples were collected from water treatment plants (WTPs) that employ conventional methodologies for water purification including filtration, flocculation, sedimentation and disinfection. The Ife dam is the smallest $\left(0.95 \mathrm{~km}^{2}\right)$ and is located at Obafemi Awolowo University Ile-Ife, Osun State. The Ede Erinle dam is located in Ede, Osun State and extends approximately $14.0 \mathrm{~km}^{2}$ at the normal water level. The Eleyele dam $\left(1.5 \mathrm{~km}^{2}\right)$ services the Ibadan metropolis in Oyo State Nigeria. The Asejire dam $\left(7.5 \mathrm{~km}^{2}\right)$ is located in Asejire, approximately $30 \mathrm{~km}$ east of Ibadan. The Owena-Ondo dam $\left(7.8 \mathrm{~km}^{2}\right)$ is located near Akure town, Ondo State. The Owena-Ijesha dam $\left(1.7 \mathrm{~km}^{2}\right)$ is located near Ilesha, in Osun State. More details about each of these sample sites can be found elsewhere [27-29].

\section{Sample collection, bacteria isolation and characterization}

Water samples were collected into sterile bottles from raw, treated and municipal taps at each WTPs. Samples were collected four times during a seven month period (December, 2010 to July, 2011). Samples were serially diluted and plated on Nutrient agar, Eosin Methylene blue agar (EMB) and Deoxycholate agar (DCA). Afterwards, bacteria were picked with the goal of maximizing the diversity of colony morphology represented from each sample. Picked colonies were re-streaked on Nutrient agar to obtain pure cultures. These were subsequently transferred to Nutrient agar slants and also stored in phosphate buffer glycerol at $-80{ }^{\circ} \mathrm{C}$.

\section{Identification of bacteria using 165 rDNA sequencing}

Total genomic DNA was prepared from isolates after overnight culture in Luria Betani (LB) agar. A sample of culture was selected using a sterile plastic loop and re-suspended in $200 \mu \mathrm{l}$ of $5 \%$ Chelex 100 (BioRad) in a microcentifuge tube. The suspensions were boiled for $10 \mathrm{~min}$, followed by centrifugation for $1 \mathrm{~min}(14,000 \times g)$. A fragment of the 16S rDNA sequence was amplified using primer $16 \mathrm{~s}-8 \mathrm{~F}$ (AGAGTTTGATCMTGGCTCAG) and 16 s-517R (ATTACCGCGGCTGCTGG) [30, 31]. Extracted DNA supernatant $(5 \mu \mathrm{l})$ was used as template with $2 \mathrm{mM} \mathrm{MgCl}_{2}, 0.8 \mathrm{mM}$ dNTPs, $0.2 \mu \mathrm{M}$ of each primer and 1X PCR buffer. Reaction conditions included 1 min denaturation $\left(95^{\circ} \mathrm{C}\right)$ followed by 30 cycles of $96^{\circ} \mathrm{C}$ for $30 \mathrm{~s}, 60{ }^{\circ} \mathrm{C}$ for $30 \mathrm{~s}$ and $72{ }^{\circ} \mathrm{C}$ for $30 \mathrm{~s}$ and a final extension of $72{ }^{\circ} \mathrm{C}$ for $10 \mathrm{~min}$. PCR products were separated and visualized by gel electrophoresis (1\%) to confirm amplification. PCR products were sequenced using Big Dye Terminator chemistry (Eurofins MWG, USA) and manual base calls and sequence trimming was completed using Sequencher 5.0 (Gene Codes Corporation, Ann Arbor, MI) BLASTn [32] was used to identify the best matches from Genbank based on percent sequence identity.

\section{Antibiotic susceptibility testing}

The antibiotic resistance profile of the bacteria was determined using breakpoint assays on LB Agar plates. Agar was autoclaved, cooled to $55{ }^{\circ} \mathrm{C}$ and antibiotics were added to specific breakpoint concentration (Table 1) before agar was poured into petri dishes $(150 \times 15 \mathrm{~mm})$. Bacteria were retrieved from freezer stocks and transferred from 
Table 1 Antibiotic concentrations tested against Gram-positive and Gram-negative bacteria

\begin{tabular}{|c|c|c|c|c|c|}
\hline \multicolumn{3}{|c|}{ Antibiotics for gram negative with concentration $(\mu \mathrm{g} / \mathrm{ml})$} & \multicolumn{3}{|c|}{ Antibiotics for gram positive with concentration $(\mu \mathrm{g} / \mathrm{ml})$} \\
\hline Code & Name & Concentration & Code & Name & Concentration \\
\hline$\overline{\mathrm{FF}}$ & Florfenicol & 16 & SU & Sulfamethoxazole & 512 \\
\hline T & Tetracycline & 16 & AM & Ampicillin & 0.5 \\
\hline S & Streptomycin & 16 & $\mathrm{~T}$ & Tetracycline & 16 \\
\hline G & Gentamycin & 16 & SXT & Sulfamethoxazole/Trimethoprim & $76 / 4$ \\
\hline K & Kanamycin & 64 & G & Gentamycin & 16 \\
\hline C & Chloramphenicol & 32 & $E$ & Erythromycin & 8 \\
\hline N & Nalidixic Acid & 30 & RIF & Rifampin & 4 \\
\hline AMC & Amoxillin/Clavulanic Acid & $32 / 16$ & LIN & Lincomycin & 4 \\
\hline CEF & Ceftiofur & 12 & CIP & Ciprofloxacin & 4 \\
\hline SU & Sulfamethoxazole & 512 & & & \\
\hline SXT & Sulfamethoxazole/Trimethoprim & $76 / 4$ & & & \\
\hline
\end{tabular}

96-well plates into another 96-well plate with sterile LB broth using a pin replicator and incubated overnight at $37{ }^{\circ} \mathrm{C}$. Cultured isolates were then re-transferred onto LB plates with the antibiotics and incubated over night at $37^{\circ} \mathrm{C}$. Isolates were scored as " 1 " for growth (resistant) or "0" for no growth (susceptible) for each antibiotic plate. A no-antibiotic plate was used to confirm successful transfer of culture to agar plates using the 96-well replicator. Isolates of bacteria that were resistant to $>3$ classes of antibiotics were considered MDR. Proportions of resistant bacteria were calculated and $95 \%$ confidence intervals were estimated based on the formula $1.96 * \operatorname{sqrt}\left[\left(\mathrm{p}^{*}(1-\mathrm{p})\right) / \mathrm{n}\right]$ where $p=$ proportion resistant and $n=$ number of isolates resistant to a given antibiotic.

\section{Genotyping of tetracycline resistance genes}

The diversity of tetracycline resistant genes encoded in the genome of 105 tetracycline and multidrug resistant isolates was assessed by testing for the presence of tetracycline resistance genes that encode resistant by efflux pump mechanism [tet $(\mathrm{A}), \operatorname{tet}(\mathrm{B}), \operatorname{tet}(\mathrm{E})$, tet30] and genes that encode ribosomal protection proteins $[\operatorname{tet}(\mathrm{M})$ and tet $(\mathrm{O})]$ (Table 2). PCR amplification reactions included $5 \mu$ l of the Chelex extracted DNA as template. The PCR reaction mixture followed the same protocol as described for $16 S$ rDNA PCR with the exception of different primer annealing temperature (Table 2).

\section{Conjugation experiments}

A nalidixic acid resistant strain of $E$. coli (DH5 $\alpha)$ was used as a recipient for conjugation experiments. A subset of isolates $(n=19)$ was selected as donor strains because they harboured a diversity of tetracycline resistance genes (tet (A), tet (B) and tet 30) while being sensitive to nalidixic acid. Overnight cultures were prepared in LB broth. Nitrocellulose membrane papers were cut $(2 \times 1 \mathrm{~cm})$ and were sterilized by using a dry cycle autoclave at $121{ }^{\circ} \mathrm{C}$ for $30 \mathrm{~min}$. The sterile filters were placed aseptically on the surface of solidified sterile LB agar. Overnight broth cultures $(10 \mu \mathrm{l})$ of both the donor and recipient bacteria were

Table 2 Primers used in this study for amplification of tetracycline-resistance genes (Call et al., 2003)

\begin{tabular}{|c|c|c|c|c|c|}
\hline Primer pair & Target & Sequence $\left(5^{\prime}-3^{\prime}\right)$ & Annealing temperature $\left({ }^{\circ} \mathrm{C}\right)$ & Amplicon size (bp) & Reference \\
\hline tet(A)- F & $\operatorname{tet}(\mathrm{A})$ & TTGGCATTCTGCATTCACTC & 60 & 494 & Call et al., 2003 \\
\hline tet(A)- $\mathrm{R}$ & & GTATAGCTTGCCGGAAGTCG & 60 & 494 & $"$ \\
\hline tet(B)- F & tet(B) & CAGTGCTGTTGTTGTCATTAA & 60 & 571 & $"$ \\
\hline tet(B)- R & & GCTTGGAATACTGAGTGTAA & 60 & 571 & \\
\hline tet(E)- F & $\operatorname{tet}(\mathrm{E})$ & TATTAACGGGCTGGCATTTC & 55 & 544 & $"$ \\
\hline tet(E)- $R$ & & AGCTGTCAGGTGGGTCAAAC & 55 & 544 & $"$ \\
\hline tet(M)- F & $\operatorname{tet}(\mathrm{M})$ & ACACGCCAGGACATATGGAT & 55 & 536 & $"$ \\
\hline tet(M)- $R$ & & ATTTCCGCAAAGTTCAGACG & 55 & 536 & $"$ \\
\hline tet(30)- F & tet(30) & CCGTCATGCAATTTGTGTTC & 55 & 550 & $"$ \\
\hline tet(30)- R & & TAGAGCACCCAGATCGTTCC & 55 & 550 & $"$ \\
\hline Tet(O)-F & $\operatorname{tet}(\mathrm{O})$ & GCGGTAATTATGGGAAACGA & 55 & 550 & $"$ \\
\hline Tet(O)-R & & TTTCCCGCTGTTCAGATTTC & & & \\
\hline
\end{tabular}


spotted together onto a filter paper and were incubated overnight at $37{ }^{\circ} \mathrm{C}$. Thereafter, $500 \mu \mathrm{l}$ of sterile phosphate buffer saline was used to wash the bacteria from the nitrocellulose paper into a sterile petri dish. A micropipette was used to transfer the fluid on to the surface of LB agar plate containing $20 \mu \mathrm{l} / \mathrm{ml}$ of nalidixic acid and $16 \mu \mathrm{l} / \mathrm{ml}$ of tetracycline followed by overnight incubation. When bacteria grew under this condition they were considered successful conjugants. DNA was extracted from representative isolates using Chelex method (described above) and used in the PCR amplification of the transferred genes for genotypic confirmation.

\section{Results and discussion}

Details on the physicochemical, microbial quality and antibiogram based on sample location of each of these water distribution systems have been reported elsewhere [27-29]. Herein we report findings for a total of 105 multi-drug resistant (MDR) bacteria that included strains with resistance to tetracycline that were selected for genotyping. Eighty-two (80.95 \%) and 23 (19.04 \%) of isolates were Gram-negative and Gram-positive, respectively. We could discern no outstanding differences between sample sites that might contribute to the variance within and between these locations. For Gram-positive bacteria resistance was detected for all antibiotics tested except ciprofloxacin (Fig. 1) whereas resistant isolates were detected for all antibiotics tested for Gram-negative bacteria (Fig. 2). The absence of ciprofloxacin resistance for the Gram-positive isolates might reflect a relatively low-level of use in Nigeria [33] or we may have adopted a breakpoint concentration that was too high to detect variation in resistance levels.

Twenty nine isolates from all sample locations possessed tetracycline-resistance genes with tet $(\mathrm{A})$ being the most

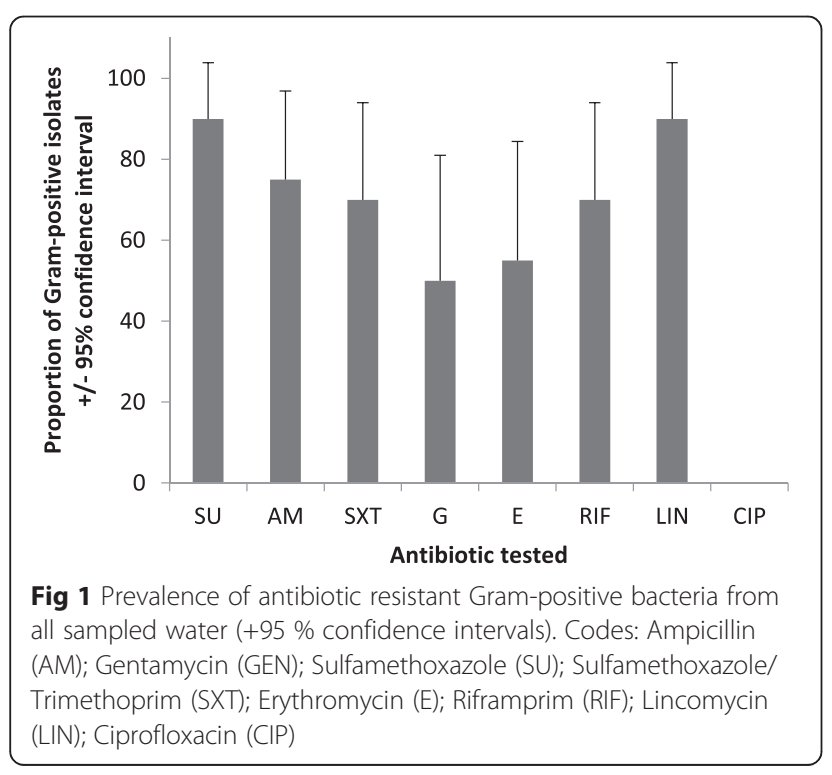

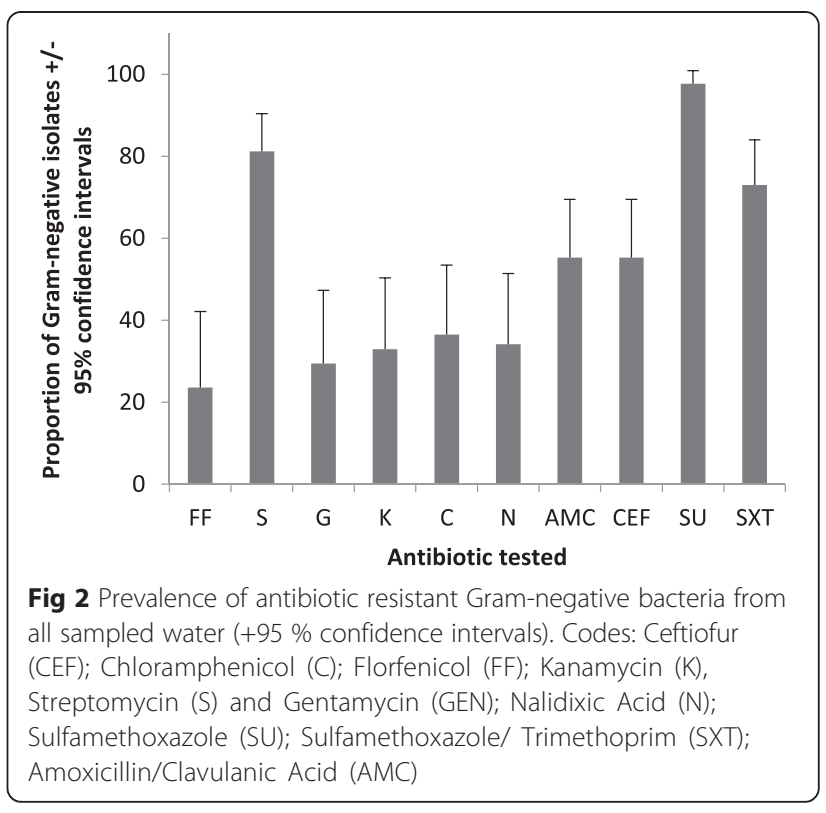

prevalent (Table 3). The two bacteria carrying tet30 were isolated from the Ede finished water and Owena-Idanre municipal tap water. 16SrDNA sequencing indicated that these two bacteria were members of the Alcaligenes genera (Table 4). This may be the first report of tet 30 in this genera indicating that this gene can be found among a wide diversity of bacteria [9].

Two Gram-positive (Bacillus sp and Leucobacter sp) and three Gram-negative bacteria (1 Proteus and 2 unidentified) harbored tet $(\mathrm{B})$ (Table 4). This gene has been reported previously in Bacillus and Proteus [34] but this may be the first report for detection of tet(B) for the genus Leucobacter. Sequence analysis of the tet (B) gene showed that it was $99 \%$ similar to tet(B) gene found in a Pseudomonas strain (accession no: AB089594.1). We surmise, however, presence of this gene in an unidentified environmental isolate implies that unidentified bacteria from the environment could be a reservoir and source of transfer to other bacteria of antibiotic resistance gene. This is similar to the report of Riesenfeld et al. [35] who also detected antibiotic resistance genes attributable to uncultured or unidentified soil bacteria.

The tet(E) gene was detected amongst a diverse group of genera (Aeromonas, Bacillus, Klebsiella, Leucobacter and Alcaligenes; Table 4). Jacobs and Chenia [36] reported that $\operatorname{tet}(\mathrm{E})$ is frequently detected among the Aeromonas in South Africa. Chopra and Roberts [11] reported that tet(E) has been found in combination with $\operatorname{tet}(\mathrm{B}), \operatorname{tet}(\mathrm{I}), \operatorname{tet}(\mathrm{C})$ tet $(\mathrm{D})$, tet 31 in the same bacteria including additional genera (Edwardsiella, Providencia, Proteus, Citrobacter, Shigella). We only found tet(E) in conjunction with tet(M), tet(A) and tet30 in Alcaligenes isolates (Table 4). Other combinations of tetracycline-resistance genes were observed in the current study for the genus Alcaligenes 
Table 3 Summary of total numbers of isolates collected per sample during the study and number positive for each tet genotype

\begin{tabular}{|c|c|c|c|c|c|c|c|}
\hline Sample site & No + ve for at least one tet gene & $\operatorname{tet}(\mathrm{A})$ & $\operatorname{tet}(\mathrm{B})$ & $\operatorname{tet}(\mathrm{E})$ & $\operatorname{tet}(\mathrm{M})$ & tet30 & Total \\
\hline \multicolumn{8}{|l|}{ Ife, Dam 1} \\
\hline Raw water & 2 & 1 & 0 & 1 & 0 & 0 & 5 \\
\hline Finished water & 3 & 1 & 0 & 1 & 1 & 0 & 7 \\
\hline Tap water & 0 & 0 & 0 & 0 & 0 & 0 & 2 \\
\hline Tap water & 0 & 0 & 0 & 0 & 0 & 0 & 0 \\
\hline \multicolumn{8}{|l|}{ Ede, Dam 2} \\
\hline Raw water & 1 & 0 & 1 & 0 & 0 & 0 & 5 \\
\hline Finished water & 2 & 2 & 0 & 0 & 0 & 1 & 3 \\
\hline Tap water & 0 & 0 & 0 & 0 & 0 & 0 & 0 \\
\hline Tap water & 0 & 0 & 0 & 0 & 0 & 0 & 1 \\
\hline \multicolumn{8}{|l|}{ Asejire Dam 3} \\
\hline Raw water & 3 & 1 & 2 & ND & ND & ND & 7 \\
\hline Finished water & 0 & 0 & 0 & 0 & 0 & 0 & 6 \\
\hline Tap water & 1 & 0 & 1 & 0 & 0 & 0 & 3 \\
\hline Tap water & 0 & 0 & 0 & 0 & 0 & 0 & 1 \\
\hline \multicolumn{8}{|l|}{ Eleyele Dam 4} \\
\hline Raw water & 1 & 0 & 0 & 0 & 1 & 0 & 11 \\
\hline Finished water & 0 & 0 & 0 & 0 & 0 & 0 & 0 \\
\hline Tap water & 1 & 0 & 0 & 1 & 0 & 0 & 1 \\
\hline Tap water & 0 & 0 & 0 & 0 & 0 & 0 & 0 \\
\hline \multicolumn{8}{|c|}{ Owena-Ondo Dam 5} \\
\hline Raw water & 0 & 0 & 0 & 0 & 0 & 0 & 0 \\
\hline Finished water & 3 & 3 & 0 & 0 & 0 & 0 & 5 \\
\hline Tap water & 1 & 1 & 0 & 0 & 0 & 0 & 6 \\
\hline Tap water & 3 & 3 & 0 & 0 & 0 & 0 & 7 \\
\hline Tap water & 1 & 0 & 0 & 0 & 1 & 0 & 8 \\
\hline \multicolumn{8}{|c|}{ Owena-ljesha Dam 6} \\
\hline Raw water & 3 & 1 & 0 & 2 & 2 & 0 & 17 \\
\hline Finished water & 0 & 0 & 0 & 0 & 0 & 0 & 1 \\
\hline Tap water & 2 & 1 & 0 & 1 & 0 & 0 & 5 \\
\hline Tap water & 2 & 2 & 0 & 2 & 0 & 1 & 4 \\
\hline Total & 29 & 16 & 4 & 8 & 5 & 2 & 105 \\
\hline
\end{tabular}

(Table 4) and Alcaligenes was the only genus with $>1$ tetracycline gene present.

The higher prevalence of tet(A) (Table 4) compared to other tetracycline resistance genes is consistent with other reports [37, 38, 34]. Multiple reports indicate that the presence of these genes among different bacteria including E.coli [39] and Aeromonas [40]. Agerso and Sandvang [41] reported tet(A) for the first time in three isolates of Alcaligenes. Bacteria of the Alcaligene genus have been isolated from intestine of humans and from various hospital or environmental water sources [42]. These strains can produce opportunistic infection, particularly for severely immune-compromised patients including those with neutropenia and malignant tumor or cardiovascular disease [43, 44].

Ribosomal protection protein genes were detected less frequently in this study; we did not detect tet $(\mathrm{O})$ while five bacteria were PCR-positive for tet(M). Another study showed that tet $(\mathrm{M})$ was widely distributed in coastal aquaculture areas and sediments in Mekong River, Vietnam [45]. Tet(M) has been found in a diversity of bacteria including Eikenella, Kingella and Neisseria [11]. We found tet(M) in Alcaligenes, Morganella and an unidentified bacterium. The distribution of tet $(\mathrm{M})$ no well described for bacteria that have less clinical significance. 
Table 4 Summary of prevalence and total number of tetracycline-resistant bacteria species and genotypes

\begin{tabular}{|c|c|c|c|c|c|}
\hline Bacteria & $\begin{array}{l}\text { No of MDR isolates } \\
\text { genotyped }\end{array}$ & $\begin{array}{l}\text { No. (\%) tetracycline } \\
\text { resistant }\end{array}$ & Source of Isolate & tet genotype & $\begin{array}{l}\text { No Positive } \\
\text { for tet gene }\end{array}$ \\
\hline Aeromonas spp & 5 & $1(3.44)$ & IRW & $\operatorname{tet}(\mathrm{E})$ & 1 \\
\hline \multirow[t]{12}{*}{ Alcaligenes spp } & \multirow[t]{12}{*}{20} & \multirow[t]{12}{*}{$10(34.48)$} & \multirow{12}{*}{$\begin{array}{l}\text { IFW, EDFW, OWODFW, OWODM2, } \\
\text { OWIRW, OWIM1, OWIM2 }\end{array}$} & $\operatorname{tet}(\mathrm{A})$ & 9 \\
\hline & & & & $\operatorname{tet}(\mathrm{E})$ & 4 \\
\hline & & & & tet(M) & 1 \\
\hline & & & & tet30 & 2 \\
\hline & & & & $\operatorname{tet}(\mathrm{A})+\operatorname{tet} 30$ & 2 \\
\hline & & & & $\operatorname{tet}(\mathrm{A})+\operatorname{tet}(\mathrm{E})$ & 3 \\
\hline & & & & $\operatorname{tet}(\mathrm{A})+\operatorname{tet}(\mathrm{M})$ & 1 \\
\hline & & & & $\operatorname{tet}(\mathrm{E})+\operatorname{tet}(\mathrm{M})$ & 1 \\
\hline & & & & $\operatorname{tet}(\mathrm{E})+\operatorname{tet} 30$ & 1 \\
\hline & & & & $\operatorname{tet}(\mathrm{A})+\operatorname{tet}(\mathrm{E})+\operatorname{tet} 30$ & 1 \\
\hline & & & & $\operatorname{tet}(\mathrm{A})+\operatorname{tet}(\mathrm{E})+\operatorname{tet}(\mathrm{M})$ & 1 \\
\hline & & & & $\operatorname{tet}(\mathrm{A})+\operatorname{tet}(\mathrm{E})+\operatorname{tet}(\mathrm{M})$ & 1 \\
\hline \multirow[t]{2}{*}{ Bacillus spp } & \multirow[t]{2}{*}{45} & \multirow[t]{2}{*}{$2(6.89)$} & \multirow[t]{2}{*}{ IFW, EDRW } & $\operatorname{tet}(\mathrm{B})$ & 1 \\
\hline & & & & $\operatorname{tet}(\mathrm{E})$ & 1 \\
\hline Klebsiella spp & 14 & $1(3.44)$ & OWIRW & $\operatorname{tet}(\mathrm{E})$ & 1 \\
\hline Leucobacter spp & 2 & $1(3.44)$ & ARW & $\operatorname{tet}(\mathrm{B})$ & 1 \\
\hline \multirow[t]{2}{*}{ Morganella spp } & \multirow[t]{2}{*}{7} & \multirow[t]{2}{*}{$6(20.69)$} & \multirow{2}{*}{$\begin{array}{l}\text { EDFW, ERW, OWODFW, OWODM1, } \\
\text { OWODM3, OWIRW }\end{array}$} & \multirow[t]{2}{*}{$\operatorname{tet}(\mathrm{A})+\operatorname{tet}(\mathrm{M})$} & 3 \\
\hline & & & & & 3 \\
\hline \multirow[t]{2}{*}{ Proteus spp } & \multirow[t]{2}{*}{22} & \multirow[t]{2}{*}{$2(6.90)$} & \multirow[t]{2}{*}{ ARW, EFW } & $\operatorname{tet}(\mathrm{A})$ & 1 \\
\hline & & & & $\operatorname{tet}(\mathrm{B})$ & 1 \\
\hline \multirow[t]{2}{*}{ Uncultured bacteria clone } & \multirow[t]{2}{*}{7} & \multirow[t]{2}{*}{$3(10.34)$} & \multirow[t]{2}{*}{ ARW, AM1 } & \multirow[t]{2}{*}{$\operatorname{tet}(\mathrm{B})+\operatorname{tet}(\mathrm{M})$} & 2 \\
\hline & & & & & 1 \\
\hline
\end{tabular}

Codes: IRW = Ife raw water, IFFW = Ife treated water, IFM1 and IFM2 = Ife municipal tap 1 and 2, EDRW = Ede raw water, EDFW=Ede treated water, EDM1 and $\mathrm{EDM} 2=$ Ede municipal tap 1 and 2, ARW = Asejire raw water, AFW = Asejire treated water, AM1 and AM2 = Asejire municipal tap 1 and 2, ERW =Eleyele raw water, EFW = Eleyele treated water, EM1 and EM2 = Eleyele municipal 1 and 2, OWODRW = Owena Ondo raw water, OWODFW = Owena Ondo treated water, OWODM1 and OWODM2 = Owena-ondo municipal tap 1 and 2, OWIRW = Owena-Idanre raw water, OWIFW = Owena-Idanre treated water, OWIM1 and OWIM2 = Owena-Idanre municipal tap 1 and 2 Note: Bacteria was identified to the genus level by $16 \mathrm{~S}$ rDNA partial Sequence

Table 5 Bacteria with transferrable tetracycline resistance genes and resistance phenotypes

\begin{tabular}{lllll}
\hline Strain ID & Bacteria/ascension no & Tetracycline resistance gene transferred $^{\text {b }}$ & Resistance phenotypes $^{\text {d }}$ \\
\hline 197 & Alcaligenes faecalis JN162124.1 & OWODFW & Tet(A) & T, S, K, CEF, AM, SXT, SU \\
198 & Alcaligenes sp. JF707602.1 & OWODFW & Tet(A) & T, S, K, AM, SXT, SU \\
173 & Alcaligenes faecalis JN162124.1 & OWIRW & Tet(A) & T, S, CEF, SXT, AMC, SU \\
210A & Escherichia coli CP003034.1 & OWODM2 & Tet(A) & T, AM, AMC, SU \\
210B & Escherichia coli CP003034.1 & OWODM2 & Tet(A) & T, AM, SXT, AMC, SU \\
46 & Proteus vulgaris JN630888.1 & ERW & Tet(B) & FF, T, S, G, K, C, AM, SXT, N, AMC, SU \\
28A & Alcaligenes faecalis HM145896.1 & EDFW & Tet30 & T, S, G, K, N, CEF, AM, SXT, SU \\
\hline
\end{tabular}

${ }^{\text {a }}$ This is our study specific ID designation

${ }^{\mathrm{b}}$ Bacteria were identified by $16 \mathrm{~S}$ rDNA partial sequencing while accenssion number is the Genbank number for the closest match

${ }^{\mathrm{C}}$ For source of bacteria and code go to Table 3 and footnote of Table 4 respectively

${ }^{d}$ Codes: Ampicillin (AM); Ceftiofur (CEF); Chloramphenicol (C) and Florfenicol (FF); Kanamycin (K), Streptomycin (S) and Gentamycin (GEN); Tetracycline (T); Nalidixic Acid (N); Sulfamethoxazole (SU); Sulfamethoxazole/ Trimethoprim (SXT); Amoxicillin/Clavulanic Acid (AMC); Erythromycin (E); Riframprim (RIF); Lincomycin (LIN); Ciprofloxacin (CIP) 
There are numerous differences between each of the sample sites that preclude drawing associations between the presence of specific resistance genes relative to different WTP practices. It was notable however, that amongst the six water distribution systems, bacteria from Dam 5 (Owena-Ondo) carried the highest proportion of tet(A) (7/ 16) (Table 3). We also observed that out of 8 bacteria tested positive for tet(E), the highest (5/8) prevalence was among bacteria from Dam 6 (Owena-Ijesha), tet(B) was found among three isolates from the raw water of Asejire and Ede water treatment plants while none of the bacteria isolated from the treated water showed the presence of this gene. Experimental manipulation and controls would be needed to determine if different WTP practices contribute to differences in the distribution of tetracycline resistance genes.

We also tested other tetracycline-resistant MDR bacteria, including strains of Acinetobacter, Aquitalae, Bordetella, Brevundimonas, Chromobacterium, Citrobacter, Camamonas, Enterobacter, Lysinibacillus, Myroides, Pantoae, Providencia, Pseudochrobactrum, Psychrobacter, Serratia, Sphingobacterium, Staphylococcus, Stenotrophomonas, Ralstonia and Trabulsiella but we did not detect any of the tetracycline-resistance genes for which we tested (data not shown). It is likely that these isolates harbor a diversity of other tetracycline-resistance gene; earlier studies identified 23 genes encoding efflux pumps and 11 genes encoding ribosomal protection proteins, not including mosaic tetracycline resistance genes [46], since the first report of transferable tetracycline resistance in 1960 [9]. It is likely that other novel tetracycline-resistance genes can be found in these environments.

Conjugation experiments showed that five of 17 tet(A) positive bacteria successfully transferred the gene to the recipient host using the conditions employed in this study (three Alcaligenes and two E. coli; Table 5). Agerso and Sandvang. [41] demonstrated the transfer of tet (A) from Alcaligenes to E.coli from their studies, results consistent with the tet(A) gene being present on a broad-host plas$\operatorname{mid}(\mathrm{s})$ that this is capable of moving between genera. Agerso et al. [47] reported that tet $(A)$ can be located on conjugative plasmids from different incompatibility groups. The one tet30-positive strain of Alcaligenes was able to transfer it to the recipient strain. Among the four bacteria carrying tet $(B)$, only the Proteus could transfer this gene.

In summary, we detected transferrable tetracycline- resistance genes among a diversity collection of bacteria, tet(A) was the most common gene detected especially from isolates from the Alcaligenes genus, and horizontal transfer was verified by conjugation experiments. Given these findings it is possible that transfer of these genes occurs regularly in water distribution system. Moreover, Gao et al. [48] noted that antibiotic-resistant bacteria could be introduced into the food chain via aquaculture products and, presumably via washing of food products.

\section{Competing interests}

The authors declare that they have no competing interests.

\section{Authors' contributions}

ATA and AAO planned this study. ATA performed the experiment in conjunction with 100 under the supervision of DRC. ATA wrote the manuscript while 100 and DRC made significant contributions to the manuscript preparation. All authors read through the manuscript and approved it.

\section{Acknowledgement}

We acknowledge the partial support from the Department of Veterinary Microbiology and Pathology and the Paul G. Allen School for Global Animal Health at, Washington State University, Pullman, USA. Lisa Orfe provided invaluable technical support.

\section{Author details}

${ }^{1}$ Department of Biological Sciences, Federal University Dutsin-Ma, Dutsin-Ma, Katsina State, Nigeria. ${ }^{2}$ Department of Microbiology, University of Ibadan, Ibadan, Oyo State, Nigeria. ${ }^{3}$ Department of Veterinary Public Health and Preventive Medicine, University of Ibadan, Ibadan, Oyo State, Nigeria. ${ }^{4}$ Paul G. Allen School for Global Animal Health, Washington State University, Pullman, Washington State, USA. ${ }^{5}$ Department of Veterinary Microbiology and

Pathology, Washington State University, Pullman, USA.

Received: 26 February 2015 Accepted: 17 June 2015

Published online: 25 June 2015

\section{References}

1. Bryskier A. Tetracyclines. In: Bryskier A, editor. Antimicrobial agents: antibacterials and antifungals. Washington: ASM Press; 2005. p. 642-51.

2. Dupont $\mathrm{HL}$, Steele $\mathrm{JH}$. The human health implications of the use of antimicrobial agents in animal feeds. Vet Q. 1987;9:309-20.

3. Schnappinger D, Hillen W. Tetracyclines: antibiotic action, uptake, and resistance mechanisms. Arch Microbiol. 1996;165:359-69.

4. Schwarz S, Roberts MC, Werckenthin C, Pang Y, Lange C. Tetracycline resistance in Staphylococcus spp. from domestic and pet animals. Vet Microbiol. 1998;63:217-28.

5. Stockstad ELR, Jukes TH, Pierce J, Page AC, Franklin AL. The multiple nature of animal protein factor. J Biol Chem. 1949;180:647-54.

6. IOM (Institute of Medicine) Division of Health Promotion and Disease Prevention). Report of a study: Human health risks with the subtherapeutic use of penicillin or tetracyclines in animal feed. Washington: National Academy Press; 1998.

7. Anonym. The Use of Drugs in Food Animals, Benefits and Risks. Washington: Committee on Drug Use in Food Animals, National Academy Press; 1999. p. 276.

8. JETACAR (Joint Expert Advisory Committee on Antibiotic Resistance). The use of antibiotics in food producing animals: antibiotic-resistant bacteria in animals and humans. Canberra: Commonwealth Department of Health and Aged Care and Commonwealth Department of Agriculture, Fisheries and Forestry; 1999. Jolliffe N., Front.

9. Roberts MC. Update on acquired tetracycline resistance genes. FEMS Microbiology and Letters. 2005;245:195-203.

10. Salyers AA, Shoemaker NB, Li LY. In the driver's seat: the Bacteroides conjugative transposons and the elements they mobilize. J Bacteriol. 1995;177:5727-31.

11. Chopra I, Roberts M. Tetracycline antibiotics: mode of action, applications, molecular biology, and epidemiology of bacterial resistance. Microbiol Mol Biol Rev. 2001;65:232-60.

12. Alonso A. Sa'nchez P, Martı'nez JL: Environmental selection of antibiotic resistance genes. Environ Microbiol. 2001;3:1-9.

13. Gilliver MA, Bennett M, Begon M, Hazel SM, Hart CA. Enterobacteria: antibiotic resistance found in wild rodents. Nature. 1999;401:233-4.

14. Jones $\mathrm{CH}$, Tuckman $\mathrm{M}$, Murphy $\mathrm{E}$, Bradford PA. Identification and sequence of a tet(M) tetracycline resistance determinant homologue in clinical isolates of Escherichia coli. J Bacteriol. 2006;188:7151-64.

15. Kobayashi T, Suehiro F, Tuyen BC, Suzuki S. Distribution and diversity of tetracycline resistance genes encoding ribosomal protection proteins in Mekong river sediments in Vietnam. FEMS Microbiol Ecol. 2007;59:729-37. 
16. Xi C, Zhang Y, Marrs CF, Ye W, Simon C. Prevalence of Antibiotic Resistance in Drinking Water Treatment and Distribution Systems. Appl Environ Microbiol. 2009;75:5714-8.

17. Scoaris DD, Colacite J, Nakamura CV, Ueda-Nakamura T, de Abreu BA, Dias BP. Virulence and antibiotic susceptibility of Aeromonas spp. isolated from drinking water. Anton Leeuw. Int J Gen Mol Microbiol. 2008;93:111-22.

18. Figueira V, Vaz-Moreira I, Silva M, Manaia CM. Diversity and antibiotic resistance of Aeromonas spp. in drinking and waste water treatment plants. Water Res. 2011;45:5599-611.

19. Storteboom H, Arabi M, Davis JG, Crimi B, Pruden A. Identification of antibiotic-resistance-gene molecular signatures suitable as tracers of pristine river, urban, and agricultural sources. Environ Sci Tech. 2010;44:1947-53.

20. Fraise AP. Susceptibility of antibiotic resistant cocci to biocides. J App Microbiol. 2002;92:158-62.

21. Rutala WA, Stiegel MM, Sarubbi FA, Weber DJ. Susceptibility of antibiotic-susceptible and antibiotic-resistant hospital bacteria to disinfectants Infect Control Hosp Epidemiol. 1997;18:417-21.

22. Armstrong JL, Calomiris JJ, Seidler RJ. Selection of antibiotic-resistant standard plate count bacteria during water treatment. Appl Environ Microbiol. 1982;1982(44):308-16.

23. Armstrong JL, Shigeno DS, Calomiris JJ, Seidler RJ. Antibiotic-resistant bacteria in drinking water. Appl Environ Microbiol. 1981;42:277-83.

24. Shrivastava R, Upreti RK, Jain SR, Prasad KN, Seth PK, Chaturvedi UC. Suboptimal chlorine treatment of drinking water leads to selection of multidrug -resistant Pseudom-onas aeruginosa. Ecotoxicol Environ Saf. 2004;58:277-83.

25. Figueira V, Serra E, Manaia CM. Differential patterns of antimicrobial resistance in population subsets of Escherichia coli isolated from waste- and surface waters. Sci Total Environ. 2011:409:1017-23.

26. Vaz-Moreira I, Nunes OC, Manaia CM. Diversity and antibiotic resistance patterns of Sphingomonadaceae isolates from drinking water. Appl Environ Microbiol. 2011;77:5697-706.

27. Adesoji AT, Ogunjobi AA. Occurrence of Multidrug-Resistant Bacteria in Selected Water Distribution Systems in Oyo State, Nigeria. Global Veterinaria. 2013;11:214-24.

28. Adesoji AT, Ogunjobi AA, Olatoye IO. Drinking Water Distribution Systems of Dams in Ondo State, Nigeria as Reservoir of Multi-Drug Resistant Bacteria. World Applied Sci J. 2014;32:403-14

29. Adesoji AT, Ogunjobi AA. Physicochemical Properties and Occurrence of Antibiotic-Resistant Bacteria in Ife and Ede Water Distribution Systems of Southwestern Nigeria. World Applied Sci J. 2013;27:1098-110.

30. Shrivastava R, Upreti RK, Jain SR, Prasad KN, Seth PK. Chaturvedi, UC: Suboptimal chlorine treatment of drinking water leads to selection of multidrug-resistant Pseudomonas aeruginosa. Ecol Environ. 2004;58:277-83.

31. Lye DJ, Dufour AP. A membrane filter procedure for assaying cytotoxic activity in heterotrophic bacteria isolated from drinking water. J Appl Bacteriol. 1991;70:89-94.

32. Altschul SF, Madden TL, Schäffer AA, Zhang J, Zhang Z, Miller W, Lipman DJ. Gapped BLAST and PSI-BLAST: a new generation of protein database search programs. Nucleic Acids Res. 1997;25:3389-402. www.ncbi.nlm.nih.gov/BLAST.

33. Yah SC, Yusuf OE, Eghafona N. Pattern of antibiotic usage by adult populations in the city of Benin, Nigeria. Sci Res Essay. 2008;3:081-5.

34. Rather MA, Aulakh RS, Singh GJP, Mir AQ, Hassan MN. Detection and sequencing of plasmid encoded tetracycline resistance determinants (tetA and tetB) from food-borne Bacillus cereus isolates. Asian Pac J Trop Med. 2012;5:709-12.

35. Riesenfeld CS, Goodman RM, Handelsman J. Uncultured soil bacteria are reservoir of new antibiotic resistance gene. Environ Microbiol. 2004;6:981-9.

36. Jacobs L, Chenia HY. Characterization of integrons and tetracycline resistance determinants in Aeromonas spp. isolated from South African aquaculture systems. Int J Food Microbiol. 2007;114:295-306.

37. Soge OO, Giardino MA, Ivanova IC, Pearson AL, Meschke JS, Roberts MC. Low prevalence of antibiotic-resistant gram-negative bacteria isolated from rural southwestern Ugandan groundwater. Water SA. 2005;35:343-8.

38. Henriques IS, Fonseca F, Alves A, Saavedra MJ, Correia A. Occurrence and diversity of integrons and $\beta$-lactamase genes among ampicillin-resistant isolates from estuarine waters. Res Microbiol. 2006;157:938-47.

39. Tuckman M, Petersen PJ, Howe AYM, Orlowski M, Mullen S, Chan K, Bradford PA, Jones CH. Occurrence of Tetracycline Resistance Genes among Escherichia coli Isolates from the Phase 3 Clinical Trials for Tigecycline. Antimicrob Agents Chemother. 2007;51:3205-11.
40. Balassiano IT, Bastos MCF, Madureira DJ, Silva IG, Freitas-Almeida AC, Oliveira SS. The involvement of tet $A$ and tetE tetracycline resistance genes in plasmid and chromosomal resistance of Aeromonas in Brazilian strains. Mem Inst Oswaldo Cruz, Rio de Janeiro. 2007;102:861-6.

41. Agers $\varnothing$ Y. and Sandvang: Class 1 Integrons and Tetracycline Resistance Genes in Alcaligenes, Arthrobacter, and Pseudomonas spp. Isolated from Pigsties and Manured Soil. Appl Environ Microbiol. 2005;71:7941-7.

42. Gurdal Y, Kemalettin A, Iftihar K, Rahmet C, Korhan A, Mehmet A. Post-ERCP bacteremia caused by Alcaligenes xylosoxidans in a patient with pancreas cancer. Ann Clin Microbiol Antimicrob. 2006;5:19-24.

43. Duggan JM, Goldstein SJ, Chenoweth CE, Kauffman CA, Bradley SF. Achromobacter xylosoxidans bacteremia: report of four cases and review of the literature. Clin Infect Dis. 1996;23:569-76.

44. Aisenberg G, Rolston KV, Safdar A. Bacteremia caused by Achromobacter and Alcaligenes species in 46 patients with cancer (1989-2003). Cancer. 2004;101:2134-40.

45. Suzuki S, Kobayashi T, Suehiro F, Tuyen BC, Tana TS. High occurrence rate of tetracycline (TC)-resistant bacteria and TC resistance genes relates to microbial diversity in sediment of Mekong river main waterway. Microbes Environ. 2008;23:149-52.

46. Patterson AJ, Rincon MT, Flint HJ, Scott KP. Mosaic tetracycline resistance genes are widespread in human and animal fecal samples. Antimicrob Agents Chemother. 2007;51:1115-8.

47. Agers $\varnothing$ Y, Pedersen AG, Aarestrup FM. Identification of Tn5397-like and Tn916-like transposons and diversity of the tetracycline resistance gene tet(M) in enterococci from humans, pigs and poultry. J Antimicrob Chemother. 2006;57:832-9.

48. Gao P, Mao D, Luo Y, Wang L, Xu B, Xu L. Occurrence of sulfonamide and tetracycline-resistant bacteria and resistance genes in aquaculture environment. Water Res. 2012:46:2355-64.

\section{Submit your next manuscript to BioMed Central and take full advantage of:}

- Convenient online submission

- Thorough peer review

- No space constraints or color figure charges

- Immediate publication on acceptance

- Inclusion in PubMed, CAS, Scopus and Google Scholar

- Research which is freely available for redistribution 